\title{
Energetic Study on Jordanian Olive Cake and Woody Biomass Materials
}

\author{
Yahya H. Khraisha \\ Chemical Engineering Department, University of Jordan, Amman, Jordan \\ Email: khraisha@ju.edu.jo,y_khraisha@yahoo.com
}

How to cite this paper: Khraisha, Y.H. (2022) Energetic Study on Jordanian Olive Cake and Woody Biomass Materials. Journal of Power and Energy Engineering, 10, 1-13.

https://doi.org/10.4236/jpee.2022.102001

Received: December 23, 2021

Accepted: February 19, 2022

Published: February 22, 2022

Copyright $\odot 2022$ by author(s) and Scientific Research Publishing Inc. This work is licensed under the Creative Commons Attribution International License (CC BY 4.0).

http://creativecommons.org/licenses/by/4.0/ (c) (i) Open Access

\begin{abstract}
In this work, the potential for energy production in Jordan was explored using four distinct types of biomass samples (olive cakes, woods). The proximate analysis, oil content, and higher heating value were all determined experimentally and compared to other biomass previously published in the literature. The findings appear to be similar to other biomass materials utilized as solid biofuel feed-stock materials. Olive cake and wood samples have lower calorific values than anthracite coal, ranging from $25 \%$ to $40 \%$ lower. According to the results of this study, olive cake samples had the highest oil extractive content (14.5 wt\%), followed by pine and beech woody samples with 8.9 $\mathrm{wt} \%$ and $3.1 \mathrm{wt} \%$, respectively. The calorific values of the biomass samples tested ranged from 18 to $22 \mathrm{MJ} / \mathrm{kg}$, making them suitable for use as fuel. Moreover, the high volatile matter content ( $78 \%$ to $93 \%$ ) was appropriate for chemical energy conversion by gasification or combustion process. Jordan can create roughly 8000 tons of pomace oil per year from the waste solid olive cake, based on existing results. Furthermore, the olive cake's energy potential in Jordan is estimated to be $38 \mathrm{MW}$ based on the higher heating value of the tested samples and the annual quantity of this resource. In the meantime, due to limited annual production, Jordanian firewood has the modest energy potential (2.4 MW).
\end{abstract}

\section{Keywords}

Biomass, Olive Cake, Proximate Analysis, Calorific Values, Soxhlet Extraction

\section{Introduction}

Biomass is biologically obtained from living, or recently living organisms and is the world's fourth-largest source of energy. Biomass, whether woody or nonwoody, is a sustainable source of energy that has been used since humans dis- 
covered how to use wood to make fires and, more recently, as a fuel for power plants [1]. Although Jordan could have great chances to utilize biomass obtained from crop residues, industry, and homes, its agricultural biomass has poor energy potential due to the country's arid climate [2]. Jordan's biofuel and waste supply have expanded fast, from 7 ktoe in 2014 to 99 ktoe in 2018, according to data from the International Energy Agency (IEA) [3]. Because of the high quality and demand, Jordan's government has initiated numerous agricultural projects to enhance the proportion of olive trees (10.5 million trees), particularly in the previous three decades [4]. As a result, Jordan became the tenth-largest producer of olive oil in the world, selling to Saudi Arabia, Oman, Japan, and the United States [4]. Forest land area was predicted to be 1.3 million Dunum $\left(1.3 \times 10^{9} \mathrm{~m}^{2}\right)$ at the end of 2018 , accounting for about 1.5 percent of Jordan's total area [5].

In Jordan, olive oil is produced by pressing or squeezing olive fruits, yielding 20,000 to 30,000 tons of olive oil and 50,000 to 60,000 tons of solid debris known as olive cake or olive pomace [6]. Olive pomace is made up of the pulp bulk, olive skin, and pit, and contains about 5\% - 8\% residual oil and trace of moisture. This waste material has a high calorific value, making it suitable for both space heating and the creation of domestic coal solid materials. Furthermore, the olive cake can be used for a variety of local uses, including animal feed, activated carbon synthesis, plant fertilizer, and compost manufacture [7] [8] [9] [10].

Olive cake and woody or non-woody biomass can be blended with oil shale (large reserve exceeds 70 billion tons [11]) and burned directly in a fluidized bed system to generate energy in Jordan. Co-firing or mixing two fuels improves combustion behavior while also increasing net calorific value, resulting in optimal operating conditions and long-term burning [12]. Khraisha et al. [13] investigated the direct combustion of olive cake in a lab-scale fluidized bed combustor (bubbling bed) and discovered that the fluidized bed approach is an excellent way to convert olive cake into a usable heat product that can be used to generate electricity at low temperatures. Finally, Jordanian forest firewood production remains quite low, at around 4210 tons per year [14]. The majority of this output went into residential heating or synthetic coal manufacture.

Several researchers have used proximate analysis (ash content, moisture content, volatile matter, and fixed carbon), the combustion bomb calorimeter (determining heating value), and the Soxhlet extraction technique (determining oil content) to characterize biomass materials and assess their energy potential [15] [16] [17] [18] [19]. As a result, a good assessment of these properties improves the design and analysis of biomass units, as well as the overall plant efficiency. On the other hand, a variety of studies have demonstrated that proximate and ultimate experimental data can be correlated to produce the high heating value (HHV) with little variance from actual results [20] [21]. Using proximate experimental data, Özyuğuran and Yaman [22] developed a number of correlations for determining high heating values. They found that satisfactory predictions could be obtained when the calorific value of biomass is greater than 20 $\mathrm{MJ} / \mathrm{kg}$. 
The goal of this study is to determine the oil content, calorific heat value, moisture content, volatile matter, ash, and fixed carbon of olive cake and woody biomass. Some correlations given by researchers were used for the calculation of heating values along with actual experimental data. Furthermore, the qualities of olive cake and the properties of wood samples are directly compared in this work. Finally, the results are compared to earlier studies and used to determine the potential of olive cake and woody biomass as an energy source in Jordan.

\section{Materials and Methods}

\subsection{Materials}

Olive oil solid wastes were collected from two Jordanian olive oil mills, one in the north (the Yarmouk district) and the other in the central area (called the Jiza district). The olive cake's solid materials were air-dried at room temperature and stored in plastic bags for future experiments. The other two woody biomass samples were from the Engineering Faculty Workshop of woods at the University of Jordan and came from "pine" and "beech" woods. The samples were stored in polyethylene bags and preserved in desiccators.

\subsection{Sample Preparation}

The air-dried olive cake samples were crushed to a particle size of less than 250 $\mu \mathrm{m}$ and stored in desiccators to prevent further air contact. The wood samples were obtained as fine particles from the sawmilling machines. Figure 1 shows a schematic diagram for the experimental work.

\subsection{Soxhlet Extraction}

Using the Soxhlet extraction apparatus, olive cake and wood samples were first treated to an extraction method. Hexane was used in the extraction process. The

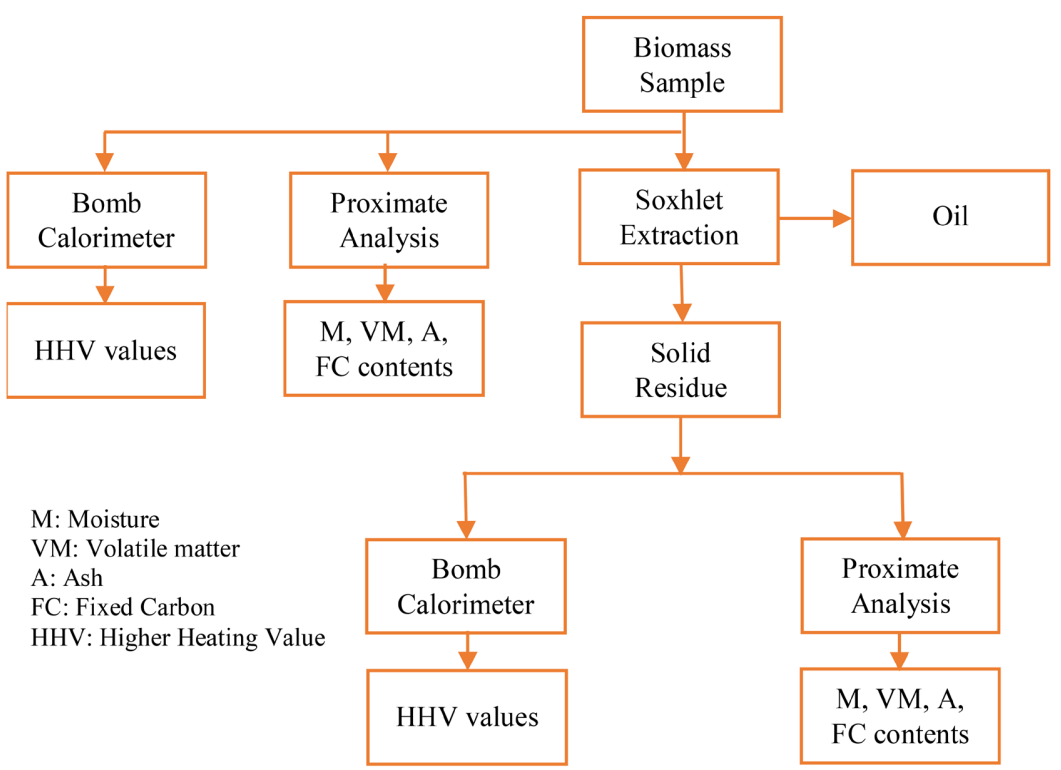

Figure 1. Schematic diagram for the experimental work. 
goal of this step is to figure out how much oil is in each sample. The amount of olive oil extracted from solid residues is affected by the nature of the olive fruit and the pressing machine conditions.

\subsection{Proximate Analysis}

All of the samples under investigation were subjected to proximate analysis before and after solvent extraction. To establish the characteristics of the biomass materials, the following tests (ASTM tests) were used:

1) Moisture content (ASTM D-3173): This test is used to define the total mass of moisture content in a biomass sample. This content was obtained by heating a known sample weight in an oven at $105^{\circ} \mathrm{C}$ without burning till constant weight. The difference between the initial and final weights represents the quantity of the moisture content in the sample;

2) Volatile matter (ASTM D-3175): This measurement is used to find the percentage of gaseous content in the sample by heating a dried sample in a covered crucible in a muffle furnace at $950^{\circ} \mathrm{C} \pm 20^{\circ} \mathrm{C}$ for 7 minutes. After cooling the crucible to ambient temperature and reweighing it again, the loss of the weight is reported as the volatile matter;

3) Ash content (ASTM D-3174): This measurement is used to obtain the contents of ash and inorganic residues after the hydrocarbons in the sample are burnt at $750^{\circ} \mathrm{C} \pm 50^{\circ} \mathrm{C}$ for one-half hour;

4) Fixed carbon: The fixed carbon content is calculated by applying the mass balance for the biomass sample.

\subsection{Heat Content}

Bomb calorimeter (Parr 6400 calorimeter) was used to measure the heat of combustion of the different samples. This technique is based on burning a known quantity of solid fuel at standard conditions and the released heat is absorbed by a known amount of water, $m_{w}$. The initial and final temperatures of water or the water temperature rise, $\Delta T$, allow obtaining the heat content, $Q_{o}$ of the tested samples ( $Q_{c}=m_{w} C_{w} \Delta T$; where $C_{w}$ is the water-specific heat). The result of the heat content, $Q_{o}$ was eventually corrected due to the heat capacity of the bomb calorimeter material and the fuse wire.

\section{Results and Discussion}

\subsection{Olive Cake Oil (Pomace Oil) and Wood Oil}

Figure 2 shows the percentage of oil content measured by the Soxhlet extraction unit for olive cake and wood samples. Olive cake samples have a higher percentage of oil content $(14 \%-15 \%)$ than wood samples, according to this figure. The extracted oil quantity in pine and beech wood samples is about 8.9 and 3.14 wt\%, respectively. Because beech is a hard and dense wood, it yields low oil content when compared to pine or olive cake materials. In other words, softwoods like pine have more extractives than hardwoods [23]. The presence of oil in olive 


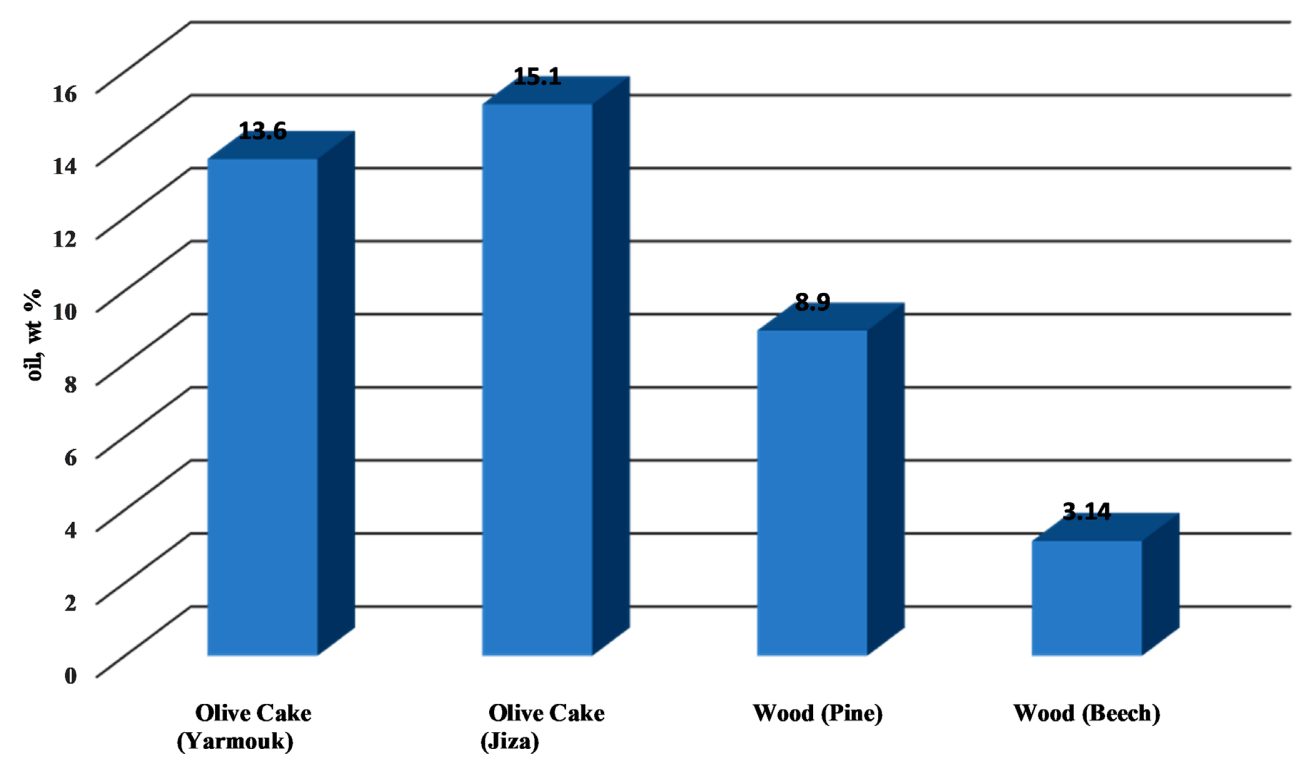

Figure 2. Oil content evaluated by Soxhlet extraction unit.

cake residue after milling extraction is influenced by a number of factors. The type and age of olive trees, the climate and weather variations, the kind of pressing machines or mills, and the operating conditions of the olive oil extraction process (traditional, 2- or 3-phase decanter process) are all factors to consider. The extracted oil from the Jiza mill's olive cake was slightly higher than that obtained from the Yarmouk mill's cake in this study. The Soxhlet extraction unit's results, on the other hand, were found to be consistent with those reported by Banat et al. [18] and Al-toom et al. [19].

Pomace oil, like other olive oils, can be used for direct human consumption (rich in monounsaturated compounds and oleanolic acid), cooking (low boiling point), and a variety of chemical industrial uses. The liquid product made from the wood samples, on the other hand, is thought to be useful for liquid fuels or valuable chemical compounds. Jordan, however, can produce roughly 8000 tons of pomace oil per year from waste solid olive cake, based on current results.

\subsection{Proximate Analysis}

Proximate analysis is a technique for characterizing biomass materials that involves determining moisture content, volatile matter, ash, and fixed carbon. The findings of the proximate analysis of the four tested substances before and after solvent extraction are shown in Figure 3 and Figure 4. Before solvent extraction, the moisture content of the examined olive cakes ranges from 2.81 to 3.75 percent, while the moisture content of wood samples ranges from 6.34 to 7.1 percent. However, after oil extraction, moisture content in olive cakes is changed to a little bit higher (6.39 - 6.85 percent), whereas it is minimally changed in sawdust wood samples (6.38 - 8.2 percent). Voća et al. [16], Chouchene et al. [24], García et al. [25], Joshua et al. [26] analyzed into various types of biomass waste 


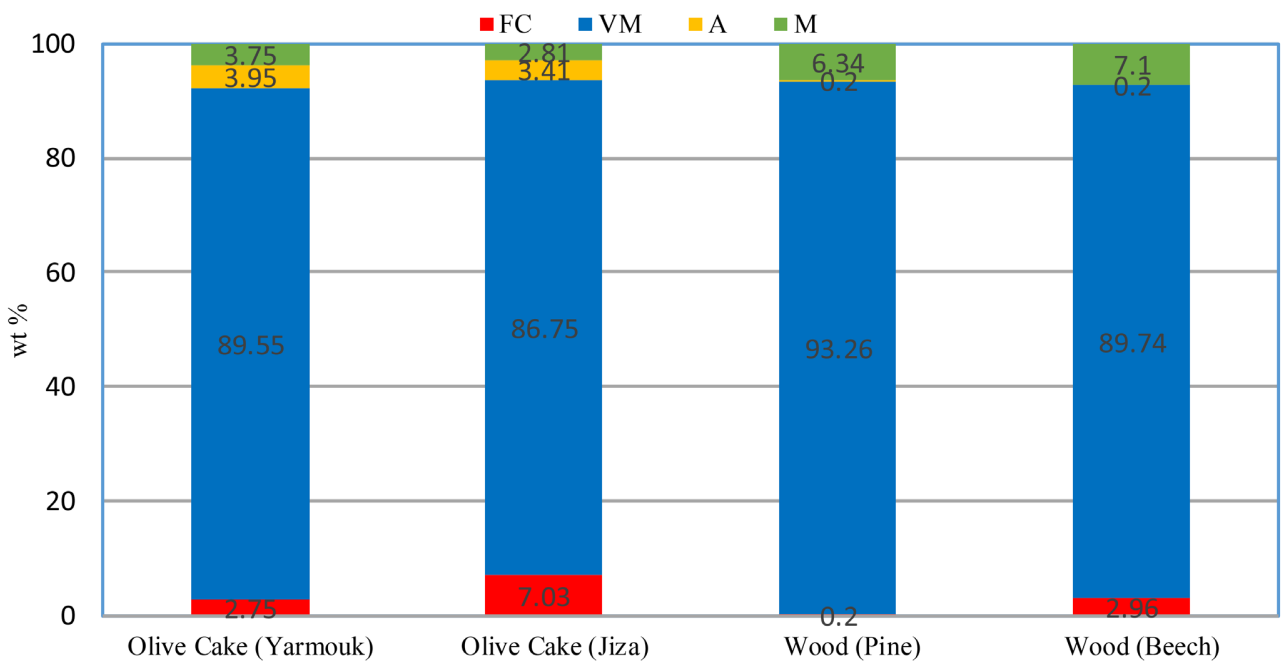

Figure 3. Proximate analysis before sample extraction (as received).

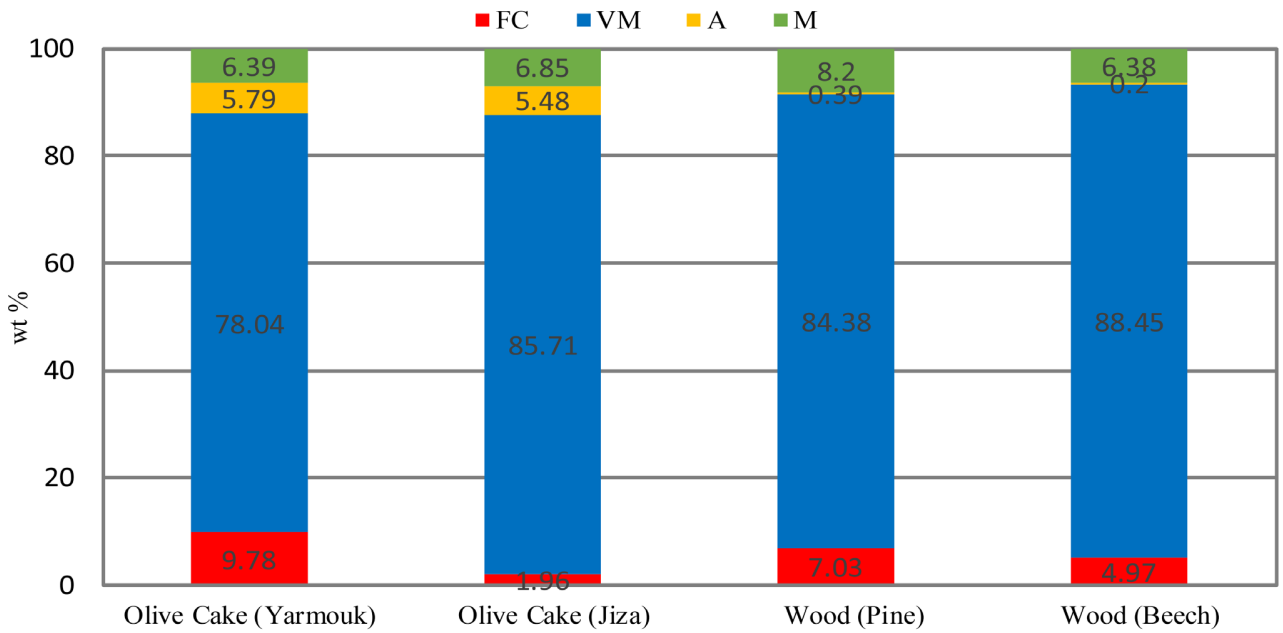

Figure 4. Proximate analysis after sample extraction (as received).

materials and found that moisture content was less than $10 \%$, which is acceptable for biomass combustion. Before and after oil extraction, the ash percentage of olive cake and wood samples ranged from $3.41-5.79$ percent and $0.20-0.39$ percent, respectively. As expected, removing oil from samples raises the ash concentration in proportion to the amount of oil removed. In general, these percentages are less than $6 \%$, indicating that these biomass products are appropriate for direct burning or briquetting. However, ash is an unwanted component since it generates environmental and health issues, as well as the need for specialized ash treatment equipment. Furthermore, high ash concentration in biomass waste materials reduces the calorific value of fuels and combustor system performance [27]. In general, the ash content results are similar to those reported by Voća et al. [16] and Demirbas and Ilten [17] for plum stone and olive residues.

The volatile chemicals generated when organic species are exposed to hightemperature levels of around $950^{\circ} \mathrm{C}$ are another important property of proximate analysis that has a substantial impact on the energy value of biomass material. 
Light hydrocarbons, $\mathrm{CO}, \mathrm{CO}_{2}, \mathrm{H}_{2}$, moisture, and tars are among the gases emitted, all of which are significant in gasification and combustion processes. In this study, the volatile matter concentration of olive cakes ranged from 78 to 90 percent, while that of wood samples ranged from 84 to 93 percent. Once again, removing residual oil from samples lowers the volatile substance levels (see Figure 3 and Figure 4). Volatile matter is plentiful in biomass waste materials, with values ranging from $75 \%$ to $90 \%$ depending on the raw material [28]. The low ash content and high volatile matter of the olive cake and wood samples indicate that the examined samples are appropriate for use as feedstock for bio-oil production.

Finally, the fixed carbon content of olive cakes ranged from $2.75 \%$ to $10 \%$, while wood samples had a fixed carbon content of $0.2 \%$ to $7 \%$. Fixed carbon levels for biomass material, according to Yao et al. [29], range from $7 \%$ to $20 \%$. The increase in carbon content could assist enhance the amount of energy used to make briquettes in terms of calorific value. Char generation via pyrolysis is favored by larger carbon content, and char burns as a solid material in combustion processes.

\subsection{Higher Heating Value (HHV)}

Finding the HHV for any biomass fuel is regarded a necessary step in evaluating its energy value and understanding its behavior during combustion and fire propagation. Figure 5 and Figure 6 depict the gross calorific values (HHV) of the examined biomass as received and dry-ash free bases, respectively, before and after solvent oil extraction. Before oil extraction, the calorific values of the investigated biomass samples show little change, with mean values of 22,046 and $17,755 \mathrm{~kJ} / \mathrm{kg}$ for olive cake and wood samples, respectively, whereas following extraction, the mean values drop to 17,992 and $17,364 \mathrm{~kJ} / \mathrm{kg}$, on an as-received

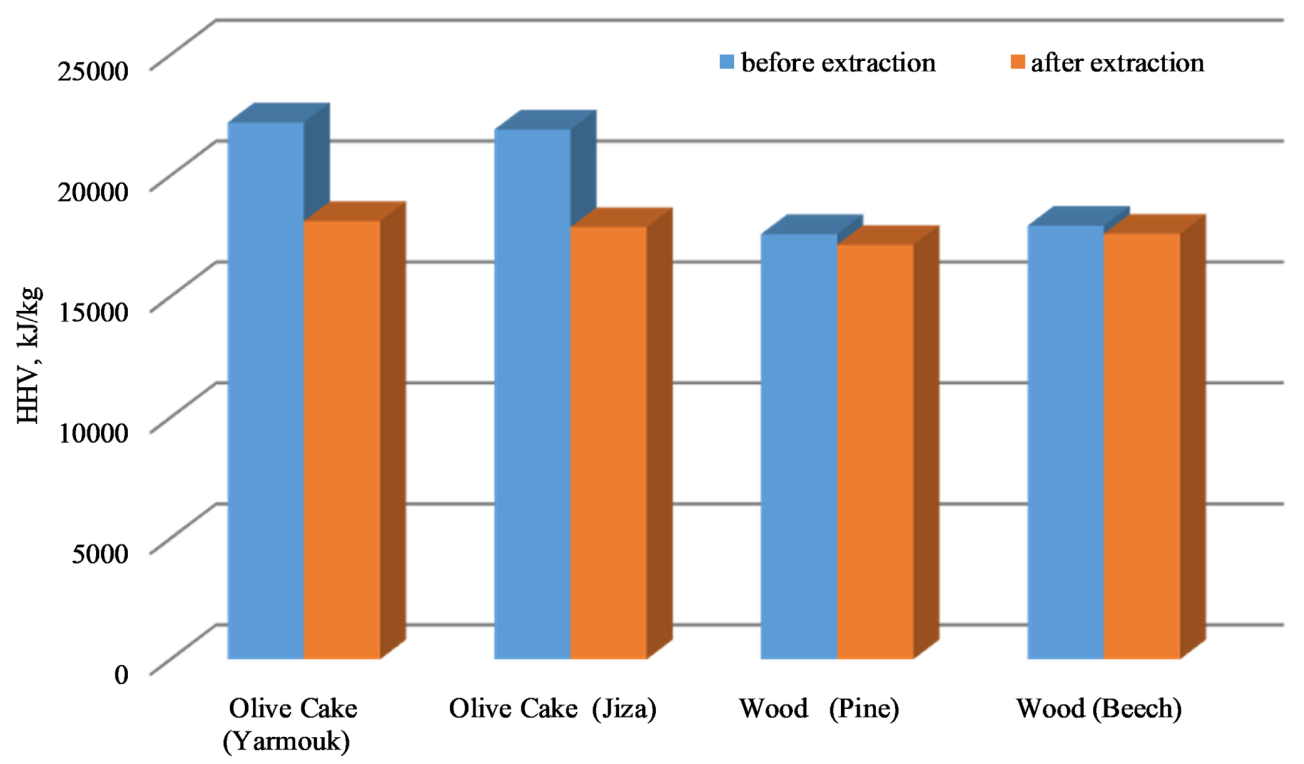

Figure 5. Calorific values before and after solvent extraction (as received). 
basis. Clearly, removing oil from wood samples has no noticeable effect on HHV (Figure 5). However, because it has higher heating values based on a dry-ash free basis, Figure 6 provides a good comparison between different biomass samples. The calorific values ranged from 18,831 to $24,042 \mathrm{~kJ} / \mathrm{kg}$, in general.

The calorific values, given by several authors, are summarized in Table 1 [15]

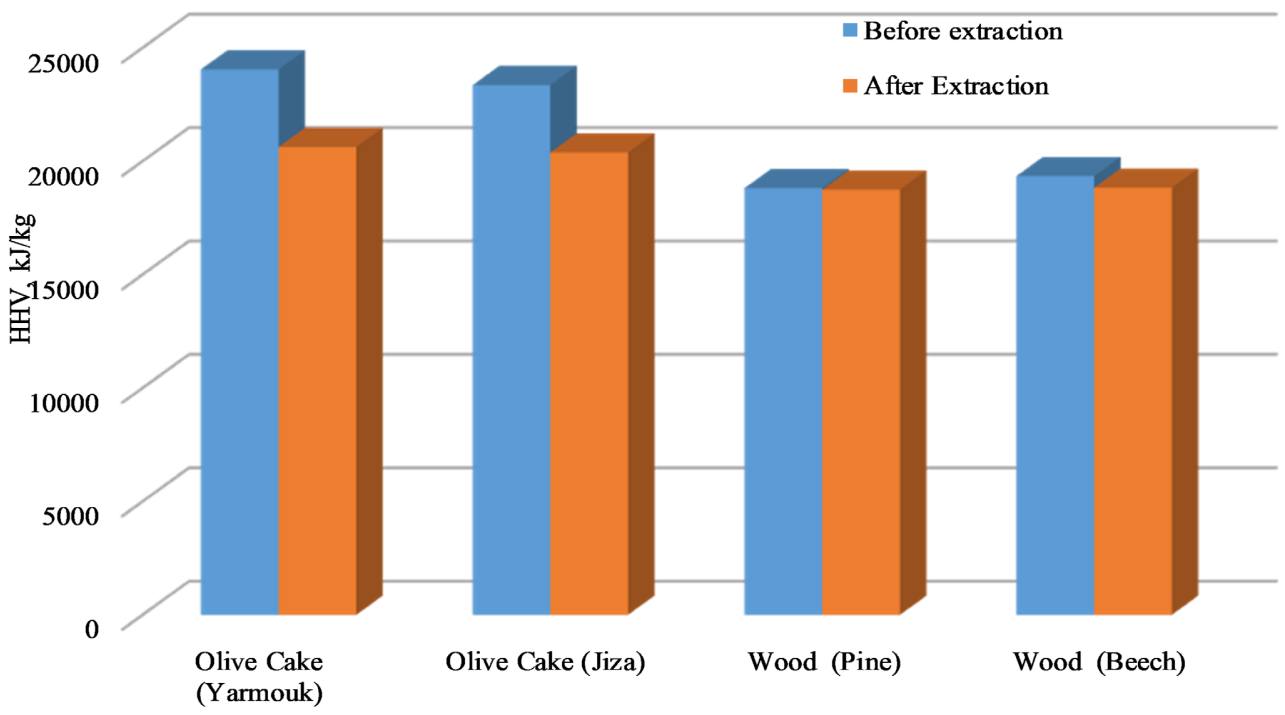

Figure 6. Calorific values before and after solvent extraction (dry-ash-free base).

Table 1. Comparison between calorific values of this work and published data.

\begin{tabular}{|c|c|c|}
\hline Material & Calorific value $\mathrm{kJ} / \mathrm{kg}$ & Reference \\
\hline \multirow[t]{2}{*}{ Olive pomace } & $17,086-23,418$ & {$[15]$} \\
\hline & 22,500 & {$[30]$} \\
\hline Olive cake & 19,810 & {$[31]$} \\
\hline Sawdust briquettete & 19,710 & {$[32]$} \\
\hline Wood fuel & 21,200 & {$[32]$} \\
\hline Woody biomass & $17,997-19,366$ & [33] \\
\hline \multicolumn{3}{|l|}{ Oil shale (Jordan) } \\
\hline Sultani field & 5444 & {$[34]$} \\
\hline Lajjun field & 8676 & {$[34]$} \\
\hline \multicolumn{3}{|l|}{ Coal } \\
\hline Lignite & 19,000 & {$[35]$} \\
\hline Anthracite & 30,000 & {$[35]$} \\
\hline \multicolumn{3}{|l|}{ This work } \\
\hline \multirow[t]{2}{*}{ Olive cake } & 17,$869 ; 18,115(\text { after })^{\mathrm{a}}$ & \\
\hline & 21,$901 ; 22,191$ (before) ${ }^{a}$ & \\
\hline \multirow[t]{2}{*}{ Wood samples } & 17,$136 ; 17,592(\text { after })^{\mathrm{a}}$ & \\
\hline & 17,$582 ; 17,927$ (before) $^{\mathrm{a}}$ & \\
\hline
\end{tabular}

${ }^{a}$ Extraction. 
[30]-[35]. The higher heating values for olive cake samples are fallen within the same range as the values obtained by several investigators as shown in Table 1. Moreover, the woody biomass samples show close calorific values as those given by Yang, H. et al. [32] and Álvarez-Álvarez, P. et al. [33]. In general, we can say that the olive cake samples behave similarly to woody biomass samples except that the presence of oil (before extraction) increases slightly their heating values. It is worth noting that the samples show HHV values of about $3-4$ times higher than those of the Jordanian oil shales [34]. This finding will enhance the co-firing technique to be utilized in electrical production from oil shale and woody biomass materials. Finally, for comparison, calorific values of olive cake and wood samples were approximately $25 \%$ - $40 \%$ lower than those of anthracite coal material [35].

\subsection{Prediction of HHV from the Proximate Analysis}

The calorific values were calculated using the following equations developed by Ayşe Özyuğuran and Serdar Yaman [22]: Equations (1) and (2).

$$
\begin{gathered}
\mathrm{HHV}=44336+286 \mathrm{FC}-(2394700 / \mathrm{VM}) \\
\mathrm{HHV}=-17507+398.5 \mathrm{VM}+287.5 \mathrm{FC}
\end{gathered}
$$

where $\mathrm{HHV}$ is the higher heating value in $\mathrm{kJ} / \mathrm{kg}, \mathrm{FC}$ is the fixed carbon weight percentage, and VM is the volatile matter percentage.

Based on moisture-free proximate values, these equations were developed by analyzing twenty-seven different biomass sources. These two equations were chosen from a list of empirical equations because they produced adequate results. Figure 7 and Figure 8 describe the relationship between experimental and expected HHVs based on Equations (1) and (2) and experimental proximate

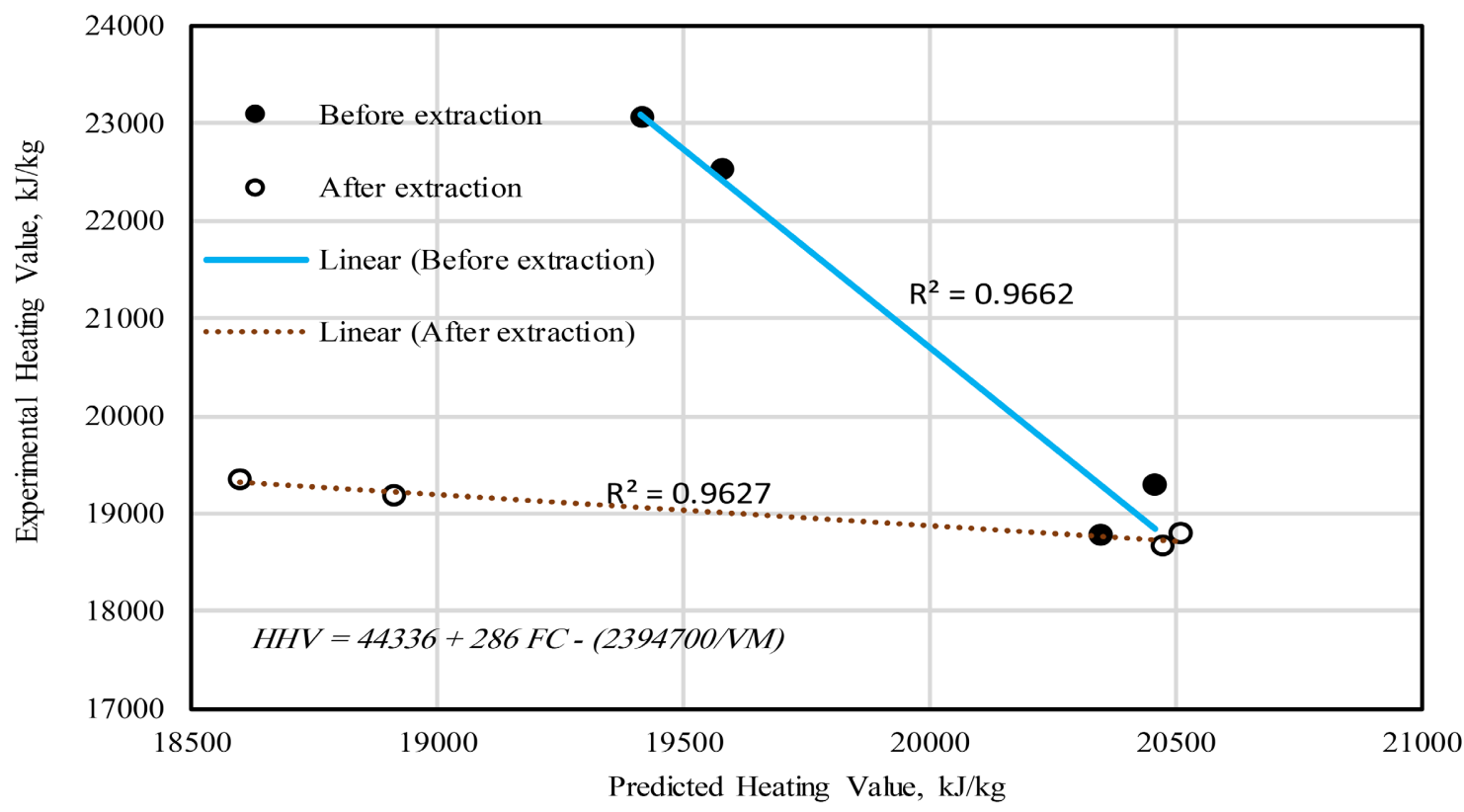

Figure 7. Relation between experimental and predicted HHV values according to Equation (1). 


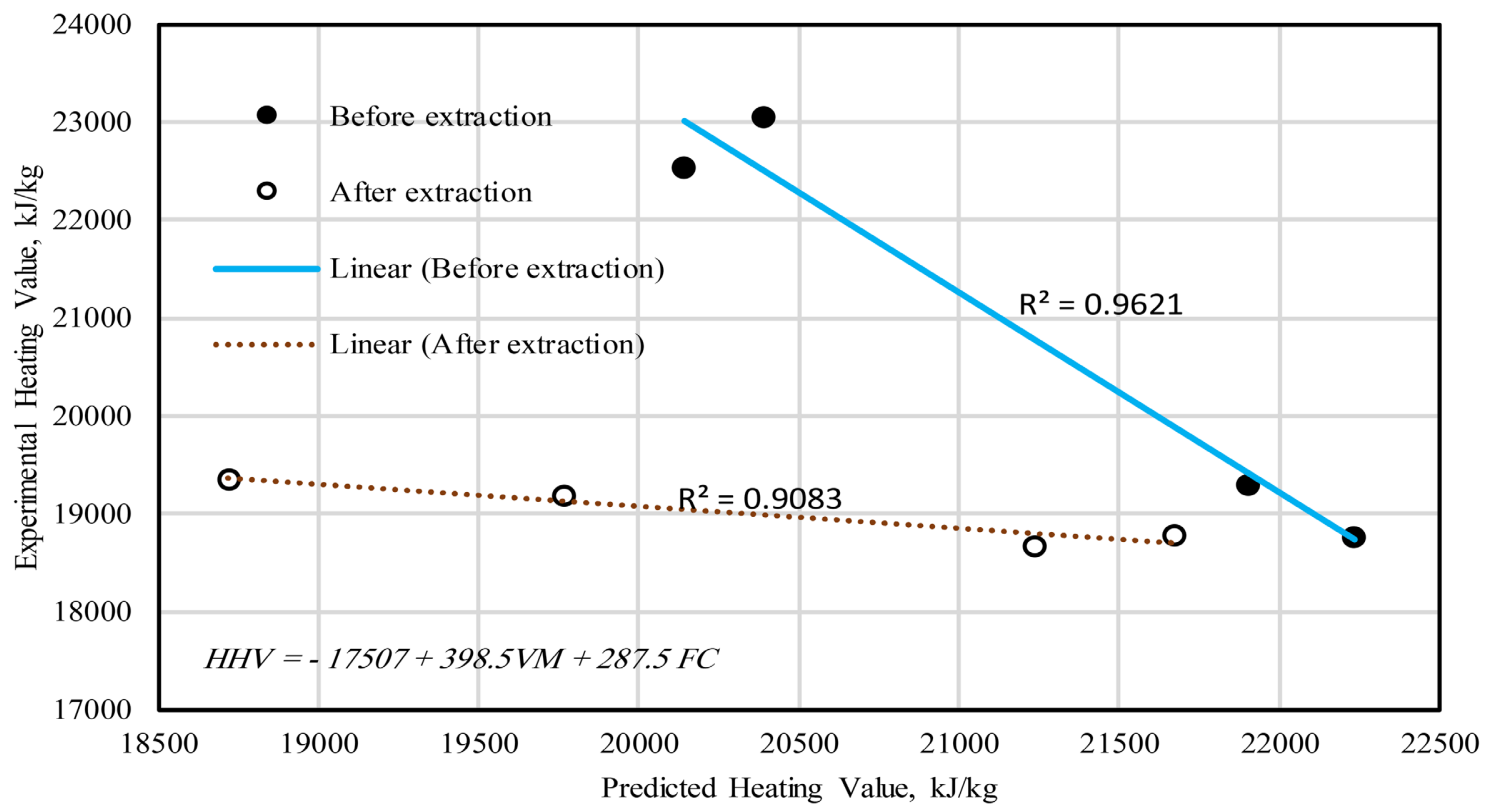

Figure 8. Relation between experimental and predicted HHV values according to Equation (2).

data. The findings show that the prediction of HHVs is quite good, with a high $\mathrm{r}^{2}$ coefficient of $0.908-0.966$. As a result, without producing a major inaccuracy, these equations can be utilized to estimate the HHVs for olive cake and wood wastes from proximate analysis data.

\subsection{Energy Potential of Olive Cake and Firewood in Jordan}

The energy potential of the olive cake in Jordan has been evaluated at $1.213 \times 10^{9}$ $\mathrm{MJ}$, which is equivalent to $38 \mathrm{MW}$, based on the average higher heating value presented in Table $1(22.046 \mathrm{MJ} / \mathrm{kg})$ and the yearly output of this source $(55,000$ tons). Jordan's government hopes to create 30 - 50 MW from biomass materials [36]. As a result, the olive cake biomass under investigation can help achieve this goal. However, because annual production is modest (4210 tons), Jordanian firewood has a low energy potential of roughly 2.4 MW (based on $17.755 \mathrm{MJ} / \mathrm{kg}$ ).

\section{Conclusion}

Olive cake, pine and beech woody samples were analyzed using Soxhlet extraction unit, bomb calorimeter and proximate analysis in order to elucidate their characteristics as fuels. The results of oil extraction revealed that wood samples obtained from pine contain more oil than ones obtained from beech, whereas, olive cake samples gave the highest oil yield of about $14.5 \mathrm{wt} \%$. Proximate analysis showed a high amount of volatile matter (87\%) and low ash content (less than 6\%), which indicated the suitability of these materials for use as feedstock for bio-oil and fuel gas production. The heating values obtained for biomass samples were in the range of $18-22 \mathrm{MJ} / \mathrm{kg}$, which were adequate to be used as fuel or in combination with other fuels. The removal of oil from the tested biomass samples showed small variation in the calorific values. Furthermore, it was possible to obtain 
satisfactory HHV predictions using empirical correlations based on dry-basis proximate analysis. Finally, based on the higher heating value and quantity of olive cake, the energy potential of this resource in Jordan has been calculated at 1.213 $\times 10^{9} \mathrm{MJ}$, which is equivalent to $38 \mathrm{MW}$. However, since Jordan has a large quantity of oil shale (more than 70 billion tons), co-combustion of this source with the biomass investigated (olive solid residues and woody materials) could be a promising answer to Jordan's energy challenges. Moreover, according to Soxhlet extraction experiments, the Jordanian olive cake can produce approximately 8000 tons of pomace oil.

\section{Acknowledgements}

The author would like to express his gratitude to Ms. Arwa Sandouqa for her invaluable assistance with the chemical analysis and sample preparation.

\section{Conflicts of Interest}

The author declares no conflicts of interest regarding the publication of this paper.

\section{References}

[1] Bhavsar, P.A., Jagadale, M.H., Khandetod, Y.P. and Mohod, A.G. (2018) Proximate Analysis of Selected Non Woody Biomass. International Journal of Current Microbiology and Applied Sciences, 7, 2846-2849. https://doi.org/10.20546/ijcmas.2018.709.353

[2] Zafar, S. (2020) Biomass Energy in Jordan. https://www.ecomena.org/biomass-energy-jordan/

[3] International Energy Agency (n.d.) Data and Statistics. https://www.iea.org/data-and-statistics

[4] The Jordan Times (2018, November) Olive Trees Cover 72\% of Jordan's Agricultural Land. https://jordantimes.com/news/local/olive-trees-cover-72-jordans-agricultural-land

[5] Department of Statistics (2015) Jordan Statistical Yearbook 2015. Department of Statistics, Amman. http://dosweb.dos.gov.jo/products/statistical-yearbook2015/

[6] Ayoub, S. (2017) Management of Olive By-Product in Jordan. The Workshop on Ensuring Sustainability of Jordanian Olive Sector, Amman, 24 April 2017.

https://www.researchgate.net/publication/317433766 Management of olive by-pr oducts in Jordan

[7] Owaimer, A.N., Kraidees, M.S., Al-Saiady, M., Zahran, S. and Abouheif, M.A. (2004) Effect of Feeding Olive Cake in Complete Diet on Performance and Nutrient Utilization of Lambs. Asian-Australasian Journal of Animal Sciences, 17, 491-496. https://doi.org/10.5713/ajas.2004.491

[8] Cibik, M. and Keles, G. (2016) Effect of Stoned Olive Cake on Milk Yield and Composition of Dairy Cows. Revue de Medicine Vétérinaire, 167, 154-158.

[9] Aljundi, I.H. and Jarrah, N. (2008) A Study of Characteristics of Activated Carbon Produced from Jordanian Olive Cake. Journal of Analytical and Applied Pyrolysis, 81, 33-36. https://doi.org/10.1016/j.jaap.2007.07.006

[10] El-Darier, S.M., Ahmed, H.A., El Razik, M.S.A. and Allam, E.S.M. (2015) Detoxifica- 
tion of Olive-mill Solid Waste and Its Probable Application as Organic Fertilizer. Journal of Fertilizers \& Pesticides, 6, Article No. 154. https://doi.org/10.4172/2471-2728.1000154

[11] Ministry of Energy and Mineral Resources (2015) MEMR Annual Report 2015. Ministry of Energy and Mineral Resources, Amman. https://memr.gov.jo/ebv4.0/root storage/en/eb list page/annual report 2015.pdf.

[12] Torres, M., Portugau, P., Castiglioni, J., Cuña, A. and Yermán, L. (2020) Co-Combustion Behaviours of a Low Calorific Uruguayan Oil Shale with Biomass Wastes. Fuel, 266, Article ID: 117118. https://doi.org/10.1016/j.fuel.2020.117118

[13] Khraisha, Y.H., Hamdan, M.A. and Qalalweh, H.S. (1999) Direct Combustion of Olive Cake Using Fluidized Bed Combustor. Energy Sources, 21, 319-327. https://doi.org/10.1080/00908319950014803

[14] Department of Statistics (2017) Jordan Statistical Yearbook 2017. Department of Statistics, Amman. http://dosweb.dos.gov.jo/products/statistical yearbook2017/

[15] Tawarah, K.M. and Rababah, R.A. (2013) Characterization of Some Jordanian Crude and Exhausted Olive Pomace Samples. Green and Sustainable Chemistry, 3, 146-162. https://doi.org/10.4236/gsc.2013.34018

[16] Voća, N., Bilandžija, N., Jurišic, V., Matin, A., Kricka, T. and Sedak, I. (2016) Proximate, Ultimate, and Energy Values Analysis of Plum Biomass By-Products Case Study: Croatia's Potential. Journal of Agricultural Science and Technology, 18, 1655-1666.

[17] Demirbas, A. and Ilten, N. (2004) Fuel Analyses and Thermochemical Processing of Olive Residues. Energy Resources, 26, 731-738.

https://doi.org/10.1080/00908310490445571

[18] Banat, F., Pal, P., Jwaied, N. and Al-Rabadi, A. (2013) Extraction of Olive Oil from Olive Cake Using Soxhlet Apparatus. American Journal of Oil and Chemical Technologies, 1, 1-8.

[19] Al-Otoom, A., Al-Asheh, S., Allawzi, M., Mahshi, K., Alzenati, N., Banat, B. and Alnimr, B. (2014) Extraction of oil from Uncrushed Olives Using Supercritical Fluid Extraction Method. The Journal of Supercritical Fluids, 95, 512-518. https://doi.org/10.1016/j.supflu.2014.10.023

[20] Demirbas, A. (1997) Calculation of High Heating Values of Biomass Fuels. Fuel, 76, 431-434. https://doi.org/10.1016/S0016-2361(97)85520-2

[21] Singh, H., Sapra, P.K. and Sidhu, B.S. (2013) Evaluation and Characterization of Different Biomass Residues through Proximate \& Ultimate Analysis and Heating Value. Asian Journal of Engineering and Applied Technology, 2, 6-10.

[22] Özyuğuran, A. and Yaman, S. (2017) Prediction of Calorific Value of Biomass from Proximate Analysis. Energy Procedia 107, 130-136. https://doi.org/10.1016/j.egypro.2016.12.149

[23] Umezawa, T. (2000) Chemistry of Extractives. In: Hon, D.N.S. and Shiraishi N. Wood and Cellulosic Chemistry, Revised, and Expanded, 2nd Edition, CRC Press, Boca Raton, 213-242. https://doi.org/10.1201/9781482269741-12

[24] Chouchene, A., Jeguirim, M., Khiari, B., Zagrouba, F. and Trouvé, G. (2010) Thermal Degradation of Olive Solid Waste: Influence of Particle Size and Oxygen Concentration. Resources, Conservation and Recycling, 54, 271-277. https://doi.org/10.1016/j.resconrec.2009.04.010

[25] García, R., Pizarro, C., Lavín, A.G. and Bueno J.L. (2012) Characterization of Spanish Biomass Wastes for Energy Use. Bioresource Technology, 103, 249-258. https://doi.org/10.1016/j.biortech.2011.10.004

[26] Joshua, J.A., Ahiekpor, J.C. and Kuye, A. (2016) Nigerian Hardwood (Nesogordonia 
Papaverifera) Sawdust Characterization: Proximate Analysis, Cellulose and Lignin Contents. Lignocellulose, 5, 50-58.

http://lignocellulose.sbu.ac.ir/Issue\%205-1.2016/Ligno 148 \%20Joshua\%20et\%20al. Nigerian\%20Hardwood\%20Sawdust\%20Characterization 50-58..pdf

[27] Loison, R., Foch P. and Boyer A. (1989) Coke Quality and Production. 2nd Edition, Butterworth's, Paris.

[28] Khan, A.A., de Jong, W., Jansens, P.J. and Spliethoff, H. (2009) Biomass Combustion in Fluidized Bed Boilers: Potential Problems and Remedies. Fuel Processing Technology, 90, 21-50. https://doi.org/10.1016/j.fuproc.2008.07.012

[29] Yao, B.Y., Changkook, R., Adela, K., Yates, N.E., Sharifi, V.N. and Swithenbank, J. (2005) Effect of Fuel Properties on Biomass Combustion. Part II. Modelling Approach Identification of the Controlling Factors. Fuel, 84, 2116-2130.

https://doi.org/10.1016/j.fuel.2005.04.023

[30] Koukouch, M.A.A., Bakhattar, I., Asbik, M., Boushaki, T., Sarh, B., Elorf, A., Cagnon, B. and Bonnamy, S. (2019) Characterization and Combustion of Olive Pomace in a Fixed Bed Boiler: Effects of Particle Sizes. International Journal of Heat and Technology, 37, 229-238. https://doi.org/10.18280/ijht.370128

[31] Atimtay, A.T. and Topal, H. (2004) Co-Combustion of Olive Cake with Lignite Coal in a Circulating Fluidized Bed. Fuel, 83, 859-867. https://doi.org/10.1016/j.fuel.2003.09.015

[32] Yang, H., Huang, L., Lin, S., Sung, K. and Sun, Y. (2016) Pyroysis Process and Characteristics of Product Sawdust Briquettes. BioResources, 11, 2438-2456. https://doi.org/10.15376/biores.11.1.2438-2456

[33] Álvarez-Álvarez, P., Pizarro, C., Barrio-Anta, M., Cámara-Obregón, A., Bueno, J.L.M., Álvarez, A., Gutiérrez, I. and Burslem, D.F.R.P. (2018) Evaluation of Tree Species for Biomass Energy Production in Northwest Spain. Forests, 9, Article No. 160. https://doi.org/10.3390/f9040160

[34] Kwadikha, A.J. (2014) Catalytic and Non-Catalytic Pyrolysis of Jordanian Oil Shales. M.Sc. Thesis, University of Jordan, Amman.

[35] Boyle, G., Everett, B. and Ramage, J. (2003) Energy Systems and Sustainability: Power for a Sustainable Future. Oxford University Press, Oxford.

[36] Wikipedia, the Free Encyclopedia (2021) Renewable Energy in Jordan. https://en.wikipedia.org/wiki/Energy in Jordan 